International Journal of Current Microbiology and Applied Sciences

ISSN: 2319-7706 Volume 6 Number 7 (2017) pp. 2537-2541

Journal homepage: http://www.ijcmas.com

Original Research Article

https://doi.org/10.20546/ijcmas.2017.607.359

\title{
Studies on the Effect of Nitrogen and Potassium on Flowering in Crossandra (Crossandra infundibuluformis L.)
}

\author{
L. Gowthami*, M.B. Nageswararao, K. Umajyothi and K. Umakrishna \\ Horticulture college and Research Institute, Dr. Y. S. R. Horticultural University, \\ Venkataramannagudem, Tadepalligudem mandal, West Godavari district, Andhra Pradesh, India \\ *Corresponding author
}

\section{A B S T R A C T}

\begin{tabular}{|l|}
\hline Ke y w o r d s \\
Crossandra, N \\
effect, K effect, \\
Flowering. \\
\hline Article Info \\
\hline $\begin{array}{l}\text { Accepted: } \\
\text { 26 June } 2017 \\
\text { Available Online: } \\
\text { 10 July } 2017\end{array}$ \\
\hline
\end{tabular}

\section{Introduction}

Fire cracker plant (Crossandra infundibuliformis L.) is native of India. It is an important group of flowering plants cultivated on a commercial scale (orange varieties) and is being grown extensively in South India. The plants are quite hardy and can be grown for flowerbeds and /or for loose flowers. The word crossandra is derived from Greek words 'krossoi' meaning fringe and 'aner' meaning male, thus word crossandra means fringed stamens. This flower is also a valuable ornamental pot flower in Sweden, Denmark and Hungary (Ottosen and Christensen, 1986). It is an evergreen shrub of minor importance. It belongs to the family Acanthaceae. It consists of five cultivars, namely, orange, yellow, red, deep orange and bluish flowered forms. The bright orange coloured flowers are widely used in temple offerings and for making gajras and venis to use as hair adornments.

\section{Materials and Methods}

The experiment was carried out during the kharif season of 2013-2014 at Horticultural College and Research Institute, Venkataramannagudem, West Godavari District of Andhra Pradesh. The experiment was laid out in a Randomized Block Design (RBD) with factorial concept replicated thrice. $\mathrm{T}_{1}\left(0 \mathrm{~kg}\right.$ nitrogen $\mathrm{ha}^{-1}+0 \mathrm{~kg}$ potassium $\left.\mathrm{ha}^{-1}\right) \mathrm{T}_{2}\left(0 \mathrm{~kg}\right.$ nitrogen ha ${ }^{-1}+60 \mathrm{~kg}$ potassium $\left.\mathrm{ha}^{-1}\right), \mathrm{T}_{3}\left(0 \mathrm{~kg}\right.$ nitrogen ha ${ }^{-1}+120 \mathrm{~kg}$ potassium ha $\left.{ }^{-1}\right), \mathrm{T}_{4}\left(0 \mathrm{~kg}\right.$ nitrogen $\mathrm{ha}^{-1}+180$ $\mathrm{kg}$ potassium ha $\left.{ }^{-1}\right), \mathrm{T}_{5}\left(50 \mathrm{~kg}\right.$ nitrogen ha ${ }^{-1}+$ 
$0 \mathrm{~kg}$ potassium $\left.\mathrm{ha}^{-1}\right), \mathrm{T}_{6}\left(50 \mathrm{~kg}\right.$ nitrogen ha ${ }^{-1}$ $+60 \mathrm{~kg}$ potassium ha $\left.{ }^{-1}\right), \mathrm{T}_{7}(50 \mathrm{~kg}$ nitrogen ha $-1+120 \mathrm{~kg}$ potassium ha $\left.{ }^{-1}\right), \mathrm{T}_{8}(50 \mathrm{~kg}$ nitrogen ha ${ }^{-1}+180 \mathrm{~kg}$ potassium ha $\left.{ }^{-1}\right) \mathrm{T}_{9}$ $\left(100 \mathrm{~kg}\right.$ nitrogen ha ${ }^{-1}+0 \mathrm{~kg}$ potassium ha $\left.{ }^{-1}\right)$, $\mathrm{T}_{10}\left(100 \mathrm{~kg}\right.$ nitrogen ha ${ }^{-1}+60 \mathrm{~kg}$ potassium $\left.\mathrm{ha}^{-1}\right) \mathrm{T}_{11}\left(100 \mathrm{~kg}\right.$ nitrogen ha ${ }^{-1}+120 \mathrm{~kg}$ potassium $\left.\mathrm{ha}^{-1}\right), \mathrm{T}_{12}\left(100 \mathrm{~kg}\right.$ nitrogen ha ${ }^{-1}+$ $180 \mathrm{~kg}$ potassium ha $\left.{ }^{-1}\right), \mathrm{T}_{13}(150 \mathrm{~kg}$ nitrogen $\mathrm{ha}^{-1}+0 \mathrm{~kg}$ potassium $\left.\mathrm{ha}^{-1}\right) \mathrm{T}_{14}(150 \mathrm{~kg}$ nitrogen ha ${ }^{-1}+0 \mathrm{~kg}$ potassium ha $\left.{ }^{-1}\right) \mathrm{T}_{15}(150$ $\mathrm{kg}$ nitrogen ha ${ }^{-1}+120 \mathrm{~kg}$ potassium ha $\left.{ }^{-1}\right) \mathrm{T}_{16}$ $\left(150 \mathrm{~kg}\right.$ nitrogen ha ${ }^{-1}+180 \mathrm{~kg}$ potassium ha $\left.{ }^{1}\right)$. The obtained data was statistically analysed (ANOVA) and presented.

\section{Results and Discussion}

\section{Number of spikes/plant}

The data recorded on number of spikes/plant as influenced by nitrogen, potassium \& their interactions at 120 and 180 DAT were presented in (Table 1). It was observed that, number of spikes/plant was significantly influenced by different levels of nitrogen at 120 DAT and at 180 DAT. Significantly maximum number of spikes/plant (32.11 at 120 DAT and 36.39 at 180 DAT) were recorded with the application of nitrogen @ $150 \mathrm{~kg} \mathrm{ha}^{-1}\left(\mathrm{~N}_{3}\right)$ followed by $100 \mathrm{~kg} \mathrm{~N}$ ha ${ }^{1}$.Maximum number of spikes/plant $(20.43$ at 120 DAT and 22.09 at 180 DAT) were recorded with the application of potassium @ $60 \mathrm{~kg} \mathrm{ha}^{-1}\left(\mathrm{~K}_{1}\right)$. Interactions had showed a significant influence on number of spikes/plant at both the stages. At 120 DAT, significantly maximum number of spikes/plant (39.81) were recorded with 150 $\mathrm{kg} \mathrm{N}+60 \mathrm{~kg} \mathrm{~K} \mathrm{ha}^{-1}\left(\mathrm{~N}_{3} \mathrm{~K}_{1}\right)$. At $180 \mathrm{DAT}$, maximum number of spikes/plant (41.17) were observed with $150 \mathrm{~kg} \mathrm{~N}+60 \mathrm{~kg} \mathrm{~K}^{-1}$ $\left(\mathrm{N}_{3} \mathrm{~K}_{1}\right)$.Number of spikes/plant was found to increase with every increase in the nitrogen level up to $150 \mathrm{~kg} \mathrm{ha}^{-1}$. Supply of potassium could bring about an improvement in this parameter up to $60 \mathrm{~kg} \mathrm{ha}^{-1}$ only. It is evident that better number of spikes per plant were recorded by nitrogen at $150 \mathrm{~kg}$ and potassium at $60 \mathrm{~kg}$ individually and also in combination. This combination could have encouraged the plant to put up more dry matter by increased photosynthetic surface or leaf area leading to better outturn of photosynthates which might have stimulated more floral buds and leading to a better number of spikes per plant. Similar results were reported by Dalvi et al., (2008), Khan et al., (2012) and Shaukat et al., (2012) in gladiolus.

\section{Number of florets/spike}

The data recorded on number of florets/spike as influenced by nitrogen, potassium \& their interactions at $120 \mathrm{DAT}$ and $180 \mathrm{DAT}$ were presented in (Table 2). Maximum number of florets/spike (538.47 at 120 DAT, 552.36 at 180 DAT) were recorded with $150 \mathrm{~kg} \mathrm{ha}^{-1}$ $\left(\mathrm{N}_{3}\right)$, followed by $100 \mathrm{~kg} \mathrm{~N}$ ha 1 , Maximum number of florets/spike (351.39 at 120 DAT and at 180 DAT 378.67) were recorded with potassium application @ $60 \mathrm{~kg} \mathrm{ha}^{-1}\left(\mathrm{~K}_{1}\right)$ which was followed by $120 \mathrm{~kg} \mathrm{ha}^{-1}\left(\mathrm{~K}_{2}\right)$. The interactions showed a significant influence on florets/spike was at $120 \mathrm{DAT}$, significantly maximum number of florets/spike (576.29) were recorded with $150 \mathrm{~kg} \mathrm{~N}+60 \mathrm{~kg} \mathrm{~K} \mathrm{ha}^{-1}$ $\left(\mathrm{N}_{3} \mathrm{~K}_{1}\right)$, followed by $100 \mathrm{~kg} \mathrm{~N}+120 \mathrm{~kg} \mathrm{~K} \mathrm{ha}^{-1}$ $\left(\mathrm{N}_{2} \mathrm{~K}_{2}\right)$. At higher nitrogen levels, more vegetative growth and more accumulation of food reserves are diverted to flower bud differentiation and resulted in more number of florets per spike. Elevated potassium level accelerated many bio-chemical reactions and led to the more number of florets per spike. The mechanism of flower bud initiation and development is closely related to the well flourished vegetative growth. Similar results were reported by Patel et al., (2010), Lehri et al., (2011) and Khan et al., (2012) in gladiolus. The increased number of florets under higher dose of nitrogen may be 
attributed to more number of floret bearing branches per plant. Similar increase in flower number with higher fertilizer levels was also noticed by Kumar et al., (2003) and Gnyandev (2006) in China aster, Saud and Ramachandra (2004) and Acharya and Dashera (2004) in marigold.

\section{Flower yield per plant $(g)$}

The data recorded on flower yield/plant (g) as influenced by nitrogen, potassium \& their interactions at 120 DAT and 180 DAT were presented in (Table 3). maximum flower yield of $480.49 \mathrm{~g}$ at $120 \mathrm{DAT}$ and $858.69 \mathrm{~g}$ at 180 DAT was recorded with nitrogen @ $150 \mathrm{~kg}$ $\mathrm{ha}^{-1}\left(\mathrm{~N}_{3}\right)$, followed by $100 \mathrm{~kg} \mathrm{~N} \mathrm{ha}{ }^{-1}$. Maximum flower yield (436.46 $\mathrm{g}$ at 120 DAT and $816.27 \mathrm{~g}$ at $180 \mathrm{DAT}$ ) was recorded with potassium application@60 $\mathrm{kg} \mathrm{ha}^{-1}\left(\mathrm{~K}_{1}\right)$ which was on par with $120 \mathrm{~kg} \mathrm{ha}^{-1}\left(\mathrm{~K}_{2}\right)$. Interactions had showed a significant influence on flower yield.

Table.1 Effect of different levels of nitrogen and potassium on number of spikes/plant in crossandra

\begin{tabular}{|c|c|c|c|c|c|c|c|c|c|c|}
\hline Treatment & \multicolumn{5}{|c|}{120 DAT } & \multicolumn{5}{|c|}{180 DAT } \\
\hline & $\mathbf{K}_{\mathbf{0}}$ & $K_{60}$ & $K_{120}$ & $K_{180}$ & Mean & $\mathbf{K}_{\mathbf{0}}$ & $K_{60}$ & $K_{120}$ & $\mathbf{K}_{180}$ & Mean \\
\hline $\mathbf{N}_{0}$ & 2.94 & 4.43 & 7.02 & 10.08 & 6.12 & 8.70 & 10.67 & 10.83 & 12.18 & 10.59 \\
\hline $\mathbf{N}_{50}$ & 11.07 & 14.40 & 16.91 & 17.44 & 14.95 & 13.93 & 15.06 & 15.61 & 17.08 & 18.42 \\
\hline $\mathbf{N}_{\mathbf{1 0 0}}$ & 22.82 & 23.09 & 32.76 & 26.79 & 25.58 & 18.35 & 21.33 & 31.98 & 25.05 & 30.94 \\
\hline $\mathbf{N}_{150}$ & 27.83 & 39.81 & 28.04 & 29.61 & 32.11 & 27.03 & 41.17 & 27.21 & 29.20 & 36.39 \\
\hline Mean & 17.39 & 21.29 & 19.64 & 20.43 & & 17.54 & 22.09 & 19.63 & 22.07 & \\
\hline Source & $\mathbf{N}$ & $\mathbf{K}$ & & $\mathbf{N} \times \mathbf{K}$ & & & $\mathbf{N}$ & $\mathbf{K}$ & & \\
\hline SE $\mathbf{m} \pm$ & 0.26 & 0.26 & & 0.32 & & & 0.49 & 0.49 & & \\
\hline CD at $5 \%$ & 0.76 & 0.76 & & 1.52 & & & 1.42 & 1.42 & & \\
\hline
\end{tabular}

Table.2 Effect of different levels of nitrogen and potassium on number of florets/spike in crossandra

\begin{tabular}{|c|c|c|c|c|c|c|c|c|c|c|}
\hline Treatment & \multicolumn{5}{|c|}{120 DAT } & \multicolumn{5}{|c|}{ 180 DAT } \\
\hline & $\mathbf{K}_{\mathbf{0}}$ & $K_{60}$ & $K_{120}$ & $K_{180}$ & Mean & $\mathbf{K}_{\mathbf{0}}$ & $K_{60}$ & $K_{120}$ & $K_{180}$ & Mean \\
\hline $\mathbf{N}_{0}$ & 20.02 & 44.11 & 97.24 & 151.65 & 78.25 & 161.32 & 175.51 & 205.40 & 226.27 & 192.12 \\
\hline $\mathbf{N}_{50}$ & 172.70 & 244.92 & 283.81 & 286.74 & 247.04 & 231.47 & 243.00 & 290.30 & 291.85 & 264.15 \\
\hline $\mathbf{N}_{100}$ & 362.04 & 418.35 & 562.01 & 473.44 & 423.32 & 369.59 & 422.73 & 573.36 & 486.45 & 434.11 \\
\hline$N_{150}$ & 439.45 & 576.29 & 521.82 & 493.74 & 538.47 & 457.67 & 581.27 & 544.72 & 510.10 & 552.36 \\
\hline Mean & 279.19 & 351.39 & 335.58 & 320.92 & & 333.94 & 378.67 & 374.52 & 355.62 & \\
\hline Source & $\mathbf{N}$ & $\mathbf{K}$ & & $\mathbf{N} \times \mathbf{K}$ & & & $\mathbf{N}$ & $\mathbf{K}$ & & \\
\hline SE $\mathbf{m} \pm$ & 0.67 & 0.67 & & 1.34 & & & 3.65 & 3.65 & & \\
\hline CD at 5\% & 1.95 & 1.95 & & 3.90 & & & 10.54 & 10.54 & & 18 \\
\hline
\end{tabular}


Table.3 Effect of different levels of nitrogen and potassium on flower yield /plant (g) in crossandra

\begin{tabular}{|c|c|c|c|c|c|c|c|c|c|c|}
\hline Treatment & \multicolumn{5}{|c|}{120 DAT } & \multicolumn{5}{|c|}{180 DAT } \\
\hline & $\mathbf{K}_{\mathbf{0}}$ & $K_{60}$ & $K_{120}$ & $K_{180}$ & Mean & $\mathbf{K}_{\mathbf{0}}$ & $K_{60}$ & $K_{120}$ & $K_{180}$ & Mean \\
\hline $\mathbf{N}_{\mathbf{0}}$ & 311.18 & 338.33 & 342.25 & 351.34 & 335.77 & 721.14 & 733.71 & 745.93 & 759.52 & 740.07 \\
\hline $\mathbf{N}_{50}$ & 363.36 & 372.49 & 385.88 & 394.37 & 379.02 & 767.37 & 776.00 & 785.97 & 799.13 & 782.11 \\
\hline $\mathbf{N}_{100}$ & 399.09 & 429.11 & 566.44 & 456.69 & 462.83 & 838.83 & 848.45 & 866.80 & 853.98 & 852.05 \\
\hline $\mathbf{N}_{150}$ & 432.28 & 582.03 & 451.29 & 456.38 & 480.49 & 850.05 & 876.18 & 856.06 & 852.48 & 858.69 \\
\hline Mean & 335.77 & 436.46 & 430.49 & 414.69 & & 794.34 & 816.27 & 813.69 & 808.58 & \\
\hline Source & $\mathbf{N}$ & $\mathbf{K}$ & & $\mathbf{N} \times \mathbf{K}$ & & & $\mathbf{N}$ & $\mathbf{K}$ & & \\
\hline SE m \pm & 0.70 & 0.70 & & 1.40 & & & 0.32 & 0.32 & & \\
\hline CD at $5 \%$ & 2.04 & 2.04 & & 4.08 & & & 0.93 & 0.93 & & \\
\hline
\end{tabular}

Table.4 Effect of different levels of nitrogen and potassium on weight of 100 flowers $(\mathrm{g})$ in crossandra

\begin{tabular}{|c|c|c|c|c|c|}
\hline \multirow[t]{2}{*}{ Nitrogen } & \multicolumn{4}{|c|}{ Potassium } & \multirow[b]{2}{*}{ Mean } \\
\hline & $\mathbf{K}_{0}$ & $K_{60}$ & $K_{120}$ & $K_{180}$ & \\
\hline $\mathbf{N}_{0}$ & 4.70 & 5.43 & 6.79 & 7.31 & 6.06 \\
\hline $\mathbf{N}_{50}$ & 8.34 & 9.21 & 10.86 & 11.43 & 9.96 \\
\hline $\mathbf{N}_{100}$ & 12.52 & 13.40 & 14.41 & 15.92 & 14.06 \\
\hline $\mathbf{N}_{150}$ & 16.10 & 19.19 & 18.17 & 17.54 & $\mathbf{1 7 . 7 5}$ \\
\hline Mean & 10.41 & 13.05 & 12.55 & 11.81 & \\
\hline Source & $\mathbf{N}$ & $\mathbf{K}$ & \multicolumn{3}{|c|}{$\mathbf{N} \times \mathbf{K}$} \\
\hline SE $\mathbf{m} \pm$ & 0.12 & 0.12 & \multicolumn{3}{|c|}{0.24} \\
\hline CD at $5 \%$ & 0.36 & 0.36 & \multicolumn{3}{|c|}{0.73} \\
\hline
\end{tabular}

Table.5 Effect of different levels of nitrogen and potassium on shelf life (days) in crossandra

\begin{tabular}{|c|c|c|c|c|c|}
\hline \multirow[t]{2}{*}{ Nitrogen } & \multicolumn{4}{|c|}{ Potassium } & \multirow[b]{2}{*}{ Mean } \\
\hline & $\mathbf{K}_{0}$ & $K_{60}$ & $K_{120}$ & $K_{180}$ & \\
\hline$\overline{N_{0}}$ & 4.72 & 5.49 & 5.65 & 5.83 & 5.42 \\
\hline $\mathbf{N}_{50}$ & 5.85 & 6.22 & 6.53 & 7.39 & 6.49 \\
\hline $\mathbf{N}_{100}$ & 7.47 & 7.77 & 9.35 & 8.27 & 8.21 \\
\hline$N_{150}$ & 8.36 & 11.95 & 8.37 & 9.00 & 9.42 \\
\hline Mean & 6.60 & 7.85 & 7.47 & 7.62 & \\
\hline Source & $\mathbf{N}$ & $\mathbf{K}$ & \multicolumn{3}{|c|}{$\mathbf{N} \times \mathbf{K}$} \\
\hline SE $\mathbf{m} \pm$ & 0.27 & 0.27 & \multicolumn{3}{|c|}{0.54} \\
\hline CD at $5 \%$ & NS & NS & \multicolumn{3}{|c|}{ NS } \\
\hline
\end{tabular}

At 120 DAT, maximum flower yield $(582.03 \mathrm{~g})$ was recorded with $150 \mathrm{~kg} \mathrm{~N}+60 \mathrm{~kg} \mathrm{~K} \mathrm{ha}^{-1}$ $\left(\mathrm{N}_{3} \mathrm{~K}_{1}\right)$, followed by $100 \mathrm{~kg} \mathrm{~N}+120 \mathrm{~kg} \mathrm{~K} \mathrm{ha}^{-1}$ $\left(\mathrm{N}_{2} \mathrm{~K}_{2}\right)$. The favourable growing environment and climatic factors will contribute for expression of maximum yield potential in the flowers (Betonia, 1996, Praneetha et al., 2002 and Talia et al., 2003).

\section{Weight of 100 flowers (g)}

The data recorded on weight of 100 flowers $(\mathrm{g})$ as influenced by nitrogen, potassium \& their interactions were presented in (Table 4). The data showed that the weight of 100 flowers increased with increasing levels of nitrogen. The maximum weight of 100 flowers (17.75 g) 
was obtained with $150 \mathrm{~kg} \mathrm{~N}^{-1}\left(\mathrm{~N}_{3}\right)$, followed by $100 \mathrm{~kg} \mathrm{~N} \mathrm{ha}^{-1}\left(\mathrm{~N}_{2}\right)$ with $14.06 \mathrm{~g}$. Among the different levels of potassium, the maximum weight of 100 flowers $(13.05 \mathrm{~g})$ was found with $60 \mathrm{~kg} \mathrm{~K} \mathrm{ha}{ }^{-1}\left(\mathrm{~K}_{1}\right)$ which was significantly superior to other treatments. The maximum weight of 100 flowers (19.19 g) was recorded with $150 \mathrm{~kg} \mathrm{~N}+60 \mathrm{~kg} \mathrm{~K} \mathrm{ha}^{-1}\left(\mathrm{~N}_{3} \mathrm{~K}_{1}\right)$ treatment combination, followed by application of $150 \mathrm{~kg}$ $\mathrm{N}+120 \mathrm{~kg} \mathrm{~K} \mathrm{ha}^{-1}\left(\mathrm{~N}_{3} \mathrm{~K}_{2}\right)$ The role of potassium in plants includes cation transport across membrane, water economy, energy metabolism and enezyme activity as stated by Mengel and Kirby (1980). Potassium increases carbon exchange and enhances carbohydrate movement (Collins and Duke, 1981) and consequently stimulates vegetative growth and decreases the translocation of photosynthates into storage organs. This result may also be due to the role of nitrogen in stimulating vegetative growth as supported by other researcher's viz., Padaganur et al., (2005) in tuberose, Pandey and Mishra (2005) in marigold.

\section{Shelf life (days)}

The data recorded on shelf life (days) as influenced by nitrogen, potassium and their interactions were presented in (Table 5). The data indicated that the levels of nitrogen, potassium and their interactions did not have significant effect on the shelf life of florets. However, maximum shelf life (9.42 days) of florets was recorded with $150 \mathrm{~kg} \mathrm{~N}^{-1}\left(\mathrm{~N}_{3}\right)$. Among the different levels of potassium, the maximum shelf life (7.85 days) of florets was recorded with $60 \mathrm{~kg} \mathrm{~K} \mathrm{ha}^{-1}\left(\mathrm{~K}_{1}\right)$ The maximum shelf life (11.95 days) of florets was recorded with $150 \mathrm{~kg} \mathrm{~N}+60 \mathrm{~kg} \mathrm{~K} \mathrm{ha}^{-1}\left(\mathrm{~N}_{3} \mathrm{~K}_{1}\right)$ treatment combinations and the minimum shelf life (4.72 days) was recorded with $0 \mathrm{~kg}$ nitrogen and potassium $\left(\mathrm{N}_{0} \mathrm{~K}_{0}\right)$. Similar findings have been obtained by Clark and Burge (1997) and Srinivas (1994) in china aster.

It can be concluded that application of 150 $\mathrm{kg} / \mathrm{ha} \mathrm{N}$ along with $60 \mathrm{~kg} / \mathrm{ha} \mathrm{K}$ would be effective in improving flowering of crossandra.

\section{References}

Acharya, M.M. and Dashora, L.K. 2004. Response of graded levels of nitrogen and phosphorus on vegetative growth and flowering in African marigold. $J$. Ornamental Hort., 7(2): 179-83.

Betonia, G.L. 1996. Germplasm collection and evaluation of different anthurium cultivars. J. Crop Sci., 20: 12.

Clark, G.E. and Burge, G.K. 1997. Effects of planting density, stem pruning treatments, and shade on secondary tuber development in Sandersonia aurantiaca. New Zealand J. Crop and Hort. Sci., 25: 73-78

Collins, M. and Duke, S.H. 1981. Influence of potassium fertilizer rate on photosynthesis and $\mathrm{N}$ fixation of alfalfa. Crop Sci., 21: 481-85.

Dalvi, N.V, Rangwala, A.D. and Joshi, G.D. 2008. Effect of spacing and graded levels of fertilizers on yield attributes of gladiolus. J. Maharashtra Agri. Univ., 33(2): 167-70.

\section{How to cite this article:}

Gowthami, L., M.B. Nageswararao, K. Umajyothi and Umakrishna, K. 2017. Studies on the Effect of Nitrogen and Potassium on Flowering in Crossandra (Crossandra Infundibuluformis L.). Int.J.Curr.Microbiol.App.Sci. 6(7): 2537-2541. doi: https://doi.org/10.20546/ijcmas.2017.607.359 